\title{
High Prevalence of Hepatitis C Infection in a Brazilian Prison: Identification of Risk Factors for Infection
}

Thaís Guimarães, Celso F. H. Granato, Drauzio Varella, Maria Lúcia G. Ferraz, Adauto Castelo and Esper Georges Kallás

\author{
Federal University of São Paulo - Medical \\ College - São paulo, SP, Brazil
}

\begin{abstract}
Hepatitis C virus (HCV) causes infectious hepatitis worldwide. It is transmitted mainly by blood products and sharing of intravenous paraphernalia during illicit drug use. High prevalence rates have been described among specific groups considered to be at higher risk for $\mathrm{HCV}$ infection, including prison inmates. The objectives of this study were: to determine the HCV seroprevalence among inmates of Casa de Detenção de São Paulo; to identify risk factors for HCV infection; and to compare the seroprevalence of $\mathrm{HCV}$ to other blood borne or sexually transmitted diseases. From December, 1993, to January, 1994, a total of 779 inmates were interviewed to collect information on sociodemographic status, sexual behavior, and past experience with illicit drugs. Blood samples were obtained from 756 inmates for serological tests. 310 (41\%) blood samples were positive for anti-HCV, $425(56.2 \%)$ were negative, and $21(2.8 \%)$ showed indeterminate results. In this population, we found a seroprevalence of $13.7 \%$ for $\mathrm{HIV}, 3.3 \%$ for syphilis (VDRL), and 68.1\% for hepatitis B virus previous infection. Four variables were each identified as associated with a positive anti-HCV serologic test: a positive VDRL (OR $=2.63$ IC 95\% 1.08 to 6.36); a time of current imprisonment longer than 130 months $(\mathrm{OR}=2.44 \mathrm{IC} 95 \%$ 1.04 to 5.71); previous incarceration at Casa de Detenção de São Paulo (OR = 1.73 IC 95\% 1.19 to 2.52) and; illicit drug use before admission to the Casa de Detenção de São Paulo (OR = 1.64 IC 95\% 1.15 to 2.33). The seroprevalence of $\mathrm{HCV}$ antibodies among the study population was high $(41 \%)$, indeed, one of the highest clusters of $\mathrm{HCV}$ infection recorded until now. Four variables were each shown to be associated with HCV infection. The simultaneous presence of these 4 variables is associated with an $82 \%$ probability of being anti-HCV positive. Although risk factor analysis indicates most $\mathrm{HCV}$ infections occur prior to inprisonment, initiation of control measures to prevent continued transmission after incarceration should be done.
\end{abstract}

Key Words: HCV, seroprevalence, prison, risk factor.

The hepatitis $\mathrm{C}$ virus (HCV) is one of the leading causes of infectious hepatitis worldwide. The major source of transmission is through blood transfusion and its derivates. However, this route alone is not enough

Received on 24 February 2001; revised 22 May 2001.

Address for correspondence: Dr. Thaís Guimarães, MD. Rua Princesa Isabel, 1472, São Paulo, SP,Zip code: 04601-003, Brazil. Phone (Fax): 55 (11) 542-3838. E-mail : tguimaraes@ wac.com.br Supported by The Fundação Saul Brandalise and the European Economic Community STDB (TS3* - CT93 - 0259). Doctors Guimarães and Kallas were supported by CAPES and CNPq.

The Brazilian Journal of Infectious Diseases 2001;5(3):111-118 (c) 2001 by The Brazilian Journal of Infectious Diseases and Contexto Publishing. All rights reserved.

$1413-8670$ to maintain the virus in humans [1]. Other routes are implicated including sexual and perinatal transmission. Percutaneous exposure also constitutes a risk factor for $\mathrm{HCV}$ infection represented by intravenous drug users, tattooing, and occupational exposure to blood.

It is very difficult to estimate the overall prevalence of HCV infection in the general population, as most studies have focused on selected groups with either high or low risk for HCV infection. The correctional population represents a selected group with high risk behavioral practices, such as homosexuality and intravenous drug use, associated to HCV transmission. Few studies have been published analyzing its prevelence in prisons. Some of these studies demonstrated that $\mathrm{HCV}$ is a significant problem in 
prisons. The overall seropositivity of $\mathrm{HCV}$ in a penitentiary in Ontario, Canada, was 39.8\% [2], while in Norway and Australia it was 57\% and 54\%, respectively, among prisoners who reported intravenous drug use [3,4].

The purpose of this study was to determine the HCV seroprevalence among male inmates from the Casa de Detenção de São Paulo, to identify independent risk factors associated with HCV infection, and to compare the seroprevalence of HCV to other blood borne or sexually transmitted diseases.

\section{Materials and Methods}

The Casa de Detenção in São Paulo includes a section of Carandiru Complex constituted by 7 pavillions housing a variable number of male prisoners. When the study began, the Casa de Detenção had 4,657 inmates. Sample size determination was based on the total number of prisoners at the time of the study, the HCV seroprevalence range of $10 \%$ to $40 \%(\mathrm{P})$, a $5 \%$ margin of error (d) for the total inmate population, and a $95 \%$ confidence interval of a $4 \%$ error in the final seroprevalence $\left(n=Z^{2}{ }_{1-} a_{12} P(1-P) / d^{2}\right)$. Assuming a seroprevalence ranging from $10 \%$ to $40 \%$, the required sample size would vary from 216 to 576 inmates. A larger sample size of inmates was chosen.

Application of a questionnaire and blood collection took place from December 20, 1993, to January 5, 1994. The number of inmates in each pavillion selected to participate in the study was proportional to the total distribution of inmates per pavillion. The questionnaire gathered information regarding demographics, prison history, and risk factors for HCV infection, obtained after consent by the inmate. All data were kept confidential. A blood sample was obtained by venipuncture and serum separated and stored at $-20^{\circ} \mathrm{C}$.

$\mathrm{HCV}$ serology was performed using an immunoenzymatic assay (INNOTEST HCV Ab III Innogenetics, Antwerp, Belgium). This test uses synthetic peptides for the core, NS3, NS4, and NS5 regions. The samples with undetermined results were submitted to an immunoblot assay (INNO-LIA HCV Ab - Innogenetics, Antwerp, Belgium).
The samples were also tested for HIV, hepatitis B virus (HBV), and syphilis. HIV serology was performed using gelatin agglutination (Fujirebio Inc., Tokyo, Japan) and fluorescence assay (bio Mérieux S.A., France and bio Mérieux Vitek, Inc., USA). Syphilis serology was performed using the Venereal Diseases Research Laboratory (VDRL) and Treponema pallidum hemagglutination assays (TPHA). HBV serology was performed using a radio-immune assay for HBsAg test (CIAE HBsAg SPRIA Kit - Department of Isotope China Institute of Atomic Energy). The inmates who had positive HBsAg samples were considered to have chronic HBV infection and the HBsAg negative or indeterminate samples were submitted to anti-HBs antibody detection (CIAE Anti-HBs SPRIA Kit Isotope Department - China Institute of Atomic Energy). HIV serology results were previously published elsewhere.

Data collection was performed using Epi Info Software, version 5.1b (World Health Organization and Centers for Disease Control and Prevention). Statistical analysis was performed using BMDP Statistical Software. Statistical significance was considered for $p$ values less than 0.05 in univariate analysis and 0.1 in multivariate analysis.

\section{Results}

During the study period, 779 questionnaires with corresponding serum samples were obtained. Twentythree individuals were excluded because the amount of blood obtained was insufficient. After these exclusions, data from 756 inmates were available for HCV testing.

The mean age was 30.2 years (median 28 years). There were $56.8 \%$ (442) whites, $26.2 \%$ (205) mulattos, and $16.9 \%$ (132) blacks. HCV serology was negative in $425(56.2 \%)$, positive in $310(41.0 \%)$ and indeterminate in $21(2.8 \%)$.

\section{Sexual behavior}

Regarding sexual activity before admission to the Casa de Detenção, 650 participants $(83.4 \%)$ claimed to have engaged in only heterosexual behavior, 118 
(15.2\%) admitted homosexual practices, and 11 (1.4\%) denied any sexual practice in their lifetime. After admission to the Casa de Detenção, these same sexual behaviors were practiced by 353 (45.2\%), 91 (11.7\%), and $335(43.1 \%)$, respectively. The majority denied any previous condom use $(714,91.7 \%)$.

In the year before admission to the Casa de Detenção, $12(1.5 \%)$ denied any sexual practice, 572 (73.5\%) had 1 to 4 sexual partners, and 195 (25.0\%) had 5 or more partners. Once inside the Casa de Detenção, 342 (43.9\%) had no sexual partner, 364 (46.7\%) had one sexual partner and $73(9.4 \%)$ had 2 or more sexual partners.

\section{Illicit drug use}

Before admission to the Casa de Detenção, 576 inmates admitted illicit drug use: 431 (55.4\%) reported only inhaled or oral drug use; and $145(18.6 \%)$ reported previous intravenous drug use; 408 inmates $(51.6 \%)$ reported illicit drug use inside Casa de Detenção, but only $11(1.4 \%)$ were intravenous users.

\section{Results of serology of other bloodborne or sexually transmitted diseases.}

The overall serological results are presented in Table 1. The data on HIV seroprevalence and risk factors for its acquisition were previously reported [5].

\section{Risk Factors for HCV infection}

Univariate analysis was performed initially to evaluate several variables included in the questionnaire. Five variables were identified as significantly associated with HCV infection: 1) younger age (mean age among HCV seronegative inmates $=29.5$ years; mean age among HCV seropositive inmates $=30.6$ years; mean age among indeterminate results $=32.0 ; \mathrm{p}=0.04) ; 2$ ) previous imprisonment in Casa de Detenção; 3) time of current imprisonment; 4) prior admission to FEBEM (a correctional facility for offenders under 18 years old); and 5) illicit drug use before and after the actual imprisonment.
Among 144 inmates that admitted illicit intravenous drug use before admission to the Casa de Detenção, the difference in seropositivity for HCV infection among those who shared syringes (48.1\%) was not statistically significant from those who did not $(40.1 \%$; $\mathrm{p}=0.39)$. Therefore, the sharing of intravenous paraphernalia was not related to HCV serostatus among those who reported illicit drug use.

Two other variables were also identified as associated with HCV infection: 1) presence of antiHIV antibodies ( $\mathrm{p}=0,007)$; and 2 ) a positive VDRL test $(\mathrm{p}=0.04)$. The association between $\mathrm{HCV}$ seropositivity and the other serological tests performed is shown in Table 2.

The independent contribution of each of these risk factors was assessed by stepwise logistic regression multivariate analysis. To categorize the continuous variables, the age was divided into two halves $(<29$ years old or equal or $>29$ years old), and the time of current imprisonment was divided into $>130$ months and $\leq 130$ months. Only time of current imprisonment, history of previous imprisonment in Casa de Detenção, positive VDRL, and illicit drug use before admission to Casa de Detenção maintained positive independent association with HCV seropositivity. The summary of the multivariate analysis is shown in Table 3.

Table 4 lists the chances of being anti-HCV positive in accordance with presence or absence of the 4 variables independently associated with $\mathrm{HCV}$ infection. The simultaneous presence of these 4 variables is associated with a probability of $82 \%$ to be anti-HCV positive. On the other hand, the absence of these variables is associated with a probability of $30 \%$ to be seropositive for $\mathrm{HCV}$.

\section{Discussion}

The data presented in this study highlight many of the current issues and concerns about the transmission of $\mathrm{HCV}$ in prisons. The seroprevalence observed in the Casa de Detenção (41\%) was considered higher when compared with the general population where the seropositivity for HCV ranges from 0.2 to $1.5 \%$ [6]. 
Table 1. Serological tests performed at Casa de Detenção de São Paulo for detection of HCV, HIV, syphilis, and HBV

\begin{tabular}{lcccccc}
\hline & Anti-HCV & Anti-HIV & VDRL & TPHA & HBsAg & Anti-HBs \\
\hline $\mathrm{N}$ & 756 & 765 & 763 & 765 & 425 & 253 \\
Negative & 425 & 636 & 738 & 678 & 254 & 117 \\
& $(56.2 \%)$ & $(83.0 \%)$ & $(96.7 \%)$ & $(88.6 \%)$ & $(59.8 \%)$ & $(46.2 \%)$ \\
Positive & 310 & 105 & 25 & 87 & 130 & 95 \\
& $(41.0 \%)$ & $(13.7 \%)$ & $(3.3 \%)$ & $(11.4 \%)$ & $(30.6 \%)$ & $(37.5 \%)$ \\
Indeterm. & 21 & 24 & 0 & 0 & 41 & 41 \\
& $(2.8 \%)$ & $(3.1 \%)$ & & & $(9.6 \%)$ & $(16.2 \%)$ \\
\hline
\end{tabular}

Table 2. Association between anti-HCV and HIV, syphilis, and HBV in study population

\begin{tabular}{|c|c|c|c|c|}
\hline Serological test & $\begin{array}{c}\text { HCV } \\
\text { Negative } \\
\text { N }(\%)\end{array}$ & $\begin{array}{c}\text { HCV } \\
\text { Positive } \\
\text { N }(\%)\end{array}$ & $\begin{array}{c}\mathrm{HCV} \\
\text { Indeterminate } \\
\mathrm{N}(\%)\end{array}$ & $P$ value \\
\hline \multicolumn{5}{|l|}{ Anti-HIV: } \\
\hline Negative & $364(58.2 \%)$ & $236(38.1 \%)$ & $19(3.1 \%)$ & \multirow{3}{*}{0.007} \\
\hline Positive & $48(46.2 \%)$ & $54(51.9 \%)$ & $2(1.9 \%)$ & \\
\hline Indetermin. & $8(33.3 \%)$ & $16(66.7 \%)$ & 0 & \\
\hline \multicolumn{5}{|l|}{ VDRL: } \\
\hline Negative & $412(57.0 \%)$ & $291(40.2 \%)$ & $20(2.8 \%)$ & \multirow{3}{*}{0.04} \\
\hline Positive & $8(32.0 \%)$ & $16(64.0 \%)$ & $1(4.0 \%)$ & \\
\hline Indetermin. & $0 \quad(0 \%)$ & $0 \quad(0 \%)$ & 0 & \\
\hline \multicolumn{5}{|l|}{ HbsAg: } \\
\hline Negative & $148(59.7 \%)$ & $97(39.1 \%)$ & $3(1.2 \%)$ & \multirow{3}{*}{0.14} \\
\hline Positive & $60(47.2 \%)$ & $66(52.0 \%)$ & $1(0.8 \%)$ & \\
\hline Indetermin. & $19(48.7 \%)$ & $20(51.3 \%)$ & $0(0 \%)$ & \\
\hline \multicolumn{5}{|l|}{ Anti-HBs: } \\
\hline Negative & $63(55.8 \%)$ & $49(43.4 \%)$ & $1(0.8 \%)$ & \multirow{3}{*}{0.61} \\
\hline Positive & $57(60.6 \%)$ & $35(37.2 \%)$ & $2(2.2 \%)$ & \\
\hline Indetermin. & $27(65.9 \%)$ & $14(34.1 \%)$ & $0 \quad(0 \%)$ & \\
\hline
\end{tabular}


Table 3. Independent risk factors associated with positive anti-HCV, identified by multi-step logistic regression multivariate analysis

\begin{tabular}{lccc}
\hline Variable & OR & IC 95\% - OR & P value \\
\hline $\begin{array}{l}\text { Time of current } \\
\text { imprisonment }>130 \text { months }\end{array}$ & 2.44 & $1.04-5.71$ & 0.029 \\
$\begin{array}{l}\text { Previous imprisonment } \\
\text { at Casa de Detenção }\end{array}$ & 1.73 & $1.19-2.52$ & 0.001 \\
$\begin{array}{l}\text { Positive VDRL } \\
\text { Illicit drug use before }\end{array}$ & 2.63 & $1.08-6.36$ & 0.014 \\
incarceration in Casa de Detenção & 1.64 & $1.15-2.33$ & 0.006 \\
\hline
\end{tabular}

Table 4. Likelihood of HCV infection estimated by multi-step logistic regression multivariate analysis

\begin{tabular}{|c|c|c|}
\hline \multicolumn{3}{|c|}{ Time of current imprisonment $>130$ months } \\
\hline & \multicolumn{2}{|c|}{ Drug use } \\
\hline Previous imprisonment & Yes & No \\
\hline $\operatorname{VDRL}(+)$ & $(*)$ & $(*)$ \\
\hline VDRL (-) & 0.75 & 0.65 \\
\hline \multicolumn{3}{|l|}{ Without imprisonment } \\
\hline $\operatorname{VDRL}(+)$ & 0.82 & $(*)$ \\
\hline VDRL (-) & 0.63 & 0.52 \\
\hline \multicolumn{3}{|c|}{ Time of current imprisonment $\leq 130$ months } \\
\hline & \multicolumn{2}{|c|}{ Drug use } \\
\hline Previous imprisonment & Yes & No \\
\hline $\operatorname{VDRL}(+)$ & 0.76 & 0.66 \\
\hline VDRL (-) & 0.55 & 0.43 \\
\hline \multicolumn{3}{|l|}{ Without imprisonment } \\
\hline VDRL (+) & 0.65 & 0.53 \\
\hline VDRL (-) & 0.41 & 0.30 \\
\hline
\end{tabular}


A similar observation was made for the others diseases studied here: $68.1 \%$ for HBV, $13.7 \%$ for HIV, and $3.3 \%$ for syphilis.

Identification of risk factors for $\mathrm{HCV}$ infection is essential for the adoption of potentially beneficial control strategies. Using univariate analysis, 7 variables were identified to be significantly associated with HCV infection: 1) younger age, 2) previous imprisonment in Casa de Detenção, 3) time of current imprisonment, 4) prior imprisonment at young offenders facility, 5) illicit drug use before and after the actual imprisonment, 6) presence of anti-HIV antibodies, and 7) a positive VDRL test. However, only 4 of these were independent risk factors by multi-step logistic regression multivariate analysis: previous imprisonment at Casa de Detenção, current imprisonment longer than 130 months, positive VDRL test, and illicit drug use before admission to Casa de Detenção.

The HCV seroprevalence observed in the correctional population indicates that this specific group is considered at risk for HCV infection. Several studies performed in Australia also demonstrated high prevalences: 39\% in 1995 [7], and 37\% in 1997 [8]. This prevalence may be atributted to the large number of inmates with behavioral risk, mainly illicit drug use.

The HIV seroprevalence observed in the Casa de Detenção places this institution among those with the highest reported rates of HIV-1 infection. Noteworthy is the fact that the incidence of $17.3 \%$ observed in 1990 , was even higher than in the present study performed in 1993 to 1994 (13.7\%) [6]. A similar observation was made in New York State prisons, where the seroprevalence among male inmates was $17 \%$ in 1987 to $1988,15 \%$ in 1990 , and $12 \%$ in 1992 . However, a different pattern of seropositivity developed among female inmates, with seroprevalence rates of $19 \%$ in 1988, and 20\% in 1992 to 1993 (data obtained from the New York State Department of Health) [9]. The reasons for this decrease in HIV seroprevalence among the male inmates is not yet well understood.

Since HIV and HCV have the same route of transmission, we would expect that the impact of control measures for HIV could also contribute to an expected decrease in $\mathrm{HCV}$ transmission. However, $\mathrm{HCV}$ is not only more prevalent than HIV among intravenous drug users, but also has the greatest infectivity [10]. So it is not surprising that these two conditions maintain a high HCV seroprevalence among drug users. Finally, the long latency of $\mathrm{HCV}$ (on average, more than 20 years) would increase the likelihood of transmission when compared with the latency of HIV (on average, less than 10 years).

Previous history of sexually transmitted diseases (STD), like syphilis and hepatitis B, was evaluated through serological tests. The data that $43.9 \%$ of inmates denied sexual practice after the admission at Casa de Detenção, and that the great majority of them denied any previous condom use, suggests that the inmates were likely exposed to $T$. pallidum before admission to the penitentiary. This seroprevalence is similar to that observed among pregnant women in Brazil [11].

The HBV seropositivity was $37.5 \%$ for anti-HBs and, unexpectedly, we found $30.6 \%$ to be $\mathrm{HBsAg}$ positive. Some explanations for this finding should be considered. First, false positive RIA results seems unlikely, since the positive samples were strongly reactive and the indeterminate results were confirmed by another method (Auszyme Monoclonal - Abbot). Second, a greater HBV exposition among the inmates. Third, the presence of immune suppression associated with drug use.

\section{Analysis of risk factors}

Age: The identification of age $<28$ years as an independent risk factor in this study, could be the result of either higher rate of illicit drug use or high risk sexual activity among younger people. Despite educational programs, younger people may be less susceptible to prevention campaigns. In addition, young inmates may be even less informed than young public school students, as evidenced by higher rates of drug use and unsafe sexual practices. Other studies have also shown a higher rate of drug use among younger inmates [12]. In addition, the significant association of previous imprisionment at a young offenders facility, and HCV seropositivity, suggests that the inmates have an early exposure to $\mathrm{HCV}$. 
Drug use: Illicit drug use (intravenous or inhaled) is clearly associated with $\mathrm{HCV}$ transmission by multi-step logistic regressionmultivariate analysis $(\mathrm{OR}=1.64, \mathrm{CI} 95 \%$ 1.15 - 2.33). The relationship between illicit drug use and crime has been the subject of intense debate. It has been suggested that drug use and prison experience are interrelated. Intense illicit drug use drives illegal behavior resulting in imprisonment; and high crime levels stimulate illicit drug use. In this study, there was a high frequency of illicit drug use prior to incarceration in the Casa de Detenção (74\%), demonstrating a rather high relationship between crime and illicit drug use in this group.

$\mathrm{HCV}$ transmission through the parenteral route was clearly established, and its transmission by blood transfusions was virtually eliminated where there was effective screening. However, this route of $\mathrm{HCV}$ transmission is maintained due to the high prevelence between drug users who share needles, syringes and other contaminated equipment [13]. Therefore, it was expected that the prevalence of blood borne pathogens was higher in the inmate population.

Several studies have described intravenous drug use inside correctional facilities as a risk factor for $\mathrm{HCV}$ infection [14]. This may be partially explained by the paucity of syringes and needles, and generally poor hygienic conditions, all favoring the sharing and reutilization of intravenous paraphernalia. Although intravenous drug use was admitted by a minority of the individuals in the Casa de Detenção, 55.4\% admitted the use of other types of illicit drugs inside the Casa de Detenção. This high rate of drug use reported by the inmates makes under reporting of intravenous drug use inside the Casa de Detenção somewhat unlikely. It has been noted that the intravenous drug use in this correctional facility has markedly decreased due to the difficulty of obtaining injection material, concern about AIDS transmission, and the widespread use of crack cocaine as opposed to intravenous cocaine.

The identification of inhalatory drug use as a risk factor for $\mathrm{HCV}$ infection requires some consideration. First, drug users who admitted inhalatory use, denied intravenous use due to the fear of discrimination. Second, HCV transmission by the inhalatory route was recently described in drug addicts [15]. The proposed mechanism would be epistaxis secondary to local trauma by the equipment (straws), and sharing it with other users.

Previous incarceration at Casa de Detenção de São Paulo: This variable was also identified as an independent risk factor for $\mathrm{HCV}$ infection $(\mathrm{OR}=1.73$, CI 95\% 1.19-2.52). This association could be due to higher rates of illicit drug use inside Casa de Detenção. Müller, et al., stated that sharing needles outside prison was not a risk factor for $\mathrm{HCV}$ infection. However, this practice inside prison was considered an important risk factor for both HIV and HCV infection [16].

Length of current imprisonment: The length of current imprisonment of $>130$ months was also an independent risk factor for $\mathrm{HCV}$ infection $(\mathrm{OR}=2.44, \mathrm{CI} 95 \% 1.04$ - 5.71), demonstrating that the longer the time in prison the higher the likelihood of HCV infection. Some studies reported that the continuous use of intravenous drugs for more than 8 years was associated with $100 \%$ of $\mathrm{HCV}$ seroprevalence, and the continuous use for more than 2 years was associated with two thirds of $\mathrm{HCV}$ seroprevalence [17]. In our study, there was a $44.2 \%$ seropositivity to HCV among the inmates who admitted drug use following admission to Casa de Detenção. Therefore, it is not surprising that individuals incarcerated for a longer time had 2.44 times greater likelihood of being $\mathrm{HCV}$ positive.

Prior imprisonment at FEBEM: The FEBEM is a correctional institution for young offenders. The significant association between this variable with seropositivity to HCV suggests that the inmates can be exposed to HCV during their time in FEBEM, where they probably have contact with illicit drugs. However, this variable may be just a marker of other variables, since it was not present as an independent risk factor after stepwise logistic regression multivariate analysis.

Presence of anti-HIV antibodies: The presence of antiHIV antibodies as a risk factor was expected, since both diseases share the same transmission routes. However, differences in their infectivity seem to affect the 
transmission inside prisons. For HCV, the viral load is constant making its parenteral transmission easy. The association between HCV and HIV has been described in several trials and may be more biological than behavioral [18]. One explanation may be that the immunosuppression caused by HIV facilitate HCV transmission [19].

Positive VDRL test: A positive VDRL test was also identified as an independent risk factor for $\mathrm{HCV}$ infection $(\mathrm{OR}=2.63$; CI 95\% 1.08 - 6.36). This correlation has been seen in groups who had hyperactive sexual behavior, suggesting that the sexual route may be an important contributor for HCV transmission [20]. Despite that sexual activity and the number of sexual partners did not demonstrate significant association with $\mathrm{HCV}$ infection, we believe that the risk of sexual transmission may be higher in persons with genital ulcers, as is the case in syphilis.

Epidemiological studies on the transmission of blood-borne pathogens in this population are important to better elucidate how efficient control initiatives should take place.

Control of $\mathrm{HCV}$ transmission among prisoners is desirable, considering that $\mathrm{HCV}$ is the cause of chronic disease in the great majority of infected subjects with unfavorable natural history. Clearly, it is a very difficult goal to accomplish. Taking into account that a significant number of inmates may have acquired HCV infection before incarceration, the impact of control measures would be limited, but is extremely important.

\section{References}

1. van Doornum G.J., Hooykass C., Cuypers M.T., et al. Prevalence of hepatitis $\mathrm{C}$ virus infections among heterossexuals with multiple partners. J Med Virol 1991;35(1):22-7.

2. Ford P.M., White C., Kaufmann H., et al. Voluntary anonymous linked study of the prevalence of HIV infection and hepatits $\mathrm{C}$ among inmates in a Canadian federal penitentiary for women. Can Med Assoc J 1995; 153(11):1605-9.

3. Holsen D.S., Harthug S., Myrmel H. Prevalence of antibodies to hepatitis $\mathrm{C}$ virus and association with intravenous drug abuse and tattooing in a national prison in Norway. Eur J Clin Microbiol Infect Dis 1993; $12: 673-6$
4. Crofts N., Hooper J., Milner R. Blood-borne virus infections among Australian injecting drug users: implications for spread of HIV. Eur J Epidemiol 1994;10:687-94.

5. Kallas E.G., Varella D., Ceneviva A.C., Castelo A. HIV seroprevalence and risk factors in a Brazilian prison. Braz J Infect Dis 1998;2(4): 197-204.

6. Alter M.J., Purcell R.H., Shih J.W. Detection of antibody to hepatitis $\mathrm{C}$ virus in prospectively followed transfusion recipients with acute chronic non-A, nonB hepatitis. N Eng J Med 1989;321:1494-1500.

7. Crofts N., Stewart T., Hearne P. Spread of bloobborne viruses among Australian prison entrants. BMJ 1995;310:285-8.

8. Butler T.G., Dolan K.A., Ferson M.J., et al. Hepatitis B and $\mathrm{C}$ in New South Wales prisons: prevalence and risk factors. MJA 1997; 166:127-30.

9. New York State Department of Health. Epidemiology: Status of HIV seroprevalence studies. Epidemiol Notes 1993;3:1-4.

10. Gerbeding J.L. Drug therapy: management of occupational exposures to blood-borne viruses, $\mathrm{N}$ Eng J Med 1995;332:444-51.

11. Boletim Epidemiológico. DST: Ministério da Saúde Coordenação Nacional de Doenças Sexualmente Transmissíveis e AIDS. Ano III N 4 - Julho a Setembro, 1997.

12. Lampinem T.M., Brewer A., Raba J. HIV in prison: a counseling opportunity. JAMA 1991;266:361.

13. Stark K., Müller R., Benzle U., et al. Frontloading: a risk factor for HIV and hepatitis $\mathrm{C}$ virus infection among injecting drug users in Berlin. AIDS 1996;10:311-7.

14. Stark K., Schreier E., Müller R., et al. Prevalence and determinants of anti-HCV seropositivity and of HCV genotype among intravenous drug users in Berlin. Scand J Infect Dis 1995;27:331-7.

15. Consensus Development Conference on Hepatitis C. National Institutes of Health (EUA), March 24-26, 1997.

16. Müller R., Stark K., Guggenmoos-Holzmann I., Bienzle U. Imprisonment: a risk factor for HIV infection counteracting education and prevention programmes for intravenous drug users. AIDS 1995;9: 183-90.

17. Bell J., Batey R.J., Farrel A.C. Hepatitis C virus in intravenous drug users. Med J Aust 1990;153:274-6.

18. Thomas D.L., Cannon L.O., Shapiro C.N., et al. Hepatitis $\mathrm{C}$, hepatitis $\mathrm{B}$ and human immunodeficiency virus infection among non-intravenous drug-using patients attending clinics for sexually transmitted diseases. J Infect Dis 1994;169:990-5.

19. Alexander T.; Gruber A., Naghavi M. Frequent patientto-patient transmission of hepatitis $\mathrm{C}$ virus in a haematology ward. Lancet 1995;345:603-7.

20. Silva M., Findor A., Roach K. Prevalence of HCV infection in a stable sexual partners of patients with chronic hepatitis C. [abstract]. Gastroenterology 1991:797. 